\title{
ESTIMATION OF MOTOR VEHICLE TOXIC EMISSIONS AND CONCENTRATIONS IN METROPOLITAN CITY OF DELHI
}

\author{
Amrit Kumar ${ }^{1}$, Rajeev Kumar Mishra ${ }^{2}$ \\ ${ }^{1,2}$ Department of Environmental Engineering, Delhi Technological University, Delhi, India
}

Received 4 August 2016; accepted 3 February 2017

\begin{abstract}
Road transport emission has been on continuous rise due to revolution in the automobile industry and public mobility demand. Emissions from motor vehicles have been one of the primary pollution sources in the metropolitan area of Delhi having a noticeable impact on ambient air quality. Volatile organic compounds, polycyclic aromatic hydrocarbons and carbonyl compounds are the major organic pollutants in urban environment. This objective of this study was to estimate the emission and concentration of Benzene, Total PAHs, and Total VOCs at 36 urban transport corridors of Delhi city. After analyzing the traffic scenario as well as toxic vehicular pollutants at all the transport corridor, the highest emission and concentration of Benzene, Total PAHs, and Total VOCs was found at ITO Bridge $(3.71 \mathrm{Kg} /$ Day; $\left.13.86 \mu \mathrm{g} / \mathrm{m}^{3}\right)$, ISBT Flyover $\left(86.22 \mathrm{Kg} /\right.$ Day; $\left.322.12 \mu \mathrm{g} / \mathrm{m}^{3}\right)$ and Nizamuddin Bridge $\left(516.44 \mathrm{Kg} /\right.$ day; $\left.1929.33 \mu \mathrm{g} / \mathrm{m}^{3}\right)$ respectively, whereas the Auchandi Road transport corridor showed the lowest emission as well as concentration of Benzene $(0.21 \mathrm{Kg} / \mathrm{Day} ; 0.78 \mu \mathrm{g} /$ $\mathrm{m}^{3}$ ) and VOCs $\left(26.91 \mathrm{Kg} /\right.$ day; $\left.100.53 \mu \mathrm{g} / \mathrm{m}^{3}\right)$. Due to comparatively very less traffic and restriction on the entry of heavy vehicles at Sansad Marg transport corridor, very low emission and concentration of PAH $\left(11.31 \mathrm{Kg} /\right.$ day; $\left.42.27 \mu \mathrm{g} / \mathrm{m}^{3}\right)$ was found.
\end{abstract}

Keywords: benzene, emission, transport corridor, total VOCs, total PAHs, vehicular emission.

\section{Introduction}

India is fast growing among the developing countries and the rapid urbanization and industrialization have resulted in the tremendous rise in population of Delhi, capital of India (Mishra et al., 2014). The environmental impacts are particularly severe in urban environment due to high urban population, traffic density, gradual increase in number of motor vehicles, driving patterns and vehicle characteristics. This alarming trend was also recorded in the National Capital Region (NCR) of Gurugram. A recent study by the Pollution Control Board observed that in addition to the vehicular emissions, the construction activities, going on all over the city, also contribute to pollution levels. Land clearing, operation of diesel engines, demolition, burning, and working with toxic materials - all these activities generate high levels of dust (Rao, Times of India, 2013). Air concentrations of a number of air pollutants in Delhi are much higher than levels recommended by the World Health Organization (Kandlikar and Ramachandran, 2000). Small ambient particles can penetrate deeply into sensitive parts of the lungs and can cause or worsen respiratory disease, such as emphysema

${ }^{2}$ Corresponding author: rajeevkumarmishra@dce.edu 
and bronchitis, and can aggravate existing heart disease, leading to increased hospital admissions and premature death (Drimal et al., 2010). These particles and other shortlived radioactive forcing agents such as ozone also absorb and scatter solar radiation affect climate, weather (Marrapu et al., 2014). This raises serious environmental concerns in terms of the fast growth of regional transport and housing sectors contributing to rapid growth of atmospheric pollutants which is backing an increase in air pollution (Chan et al., 2004; Elbir et al., 2004; Elbir et al., 2010; Guttikunda and Calori, 2013; Ministry of Finance (MoF), 2000; Mohan et al., 2007). Delhi being the national capital is one of the centers of tourism, political, socio-economic and cultural activities of the country. The city also serves the purpose of a major center of trade and commerce and it homes the intersection point for five national highways and expressways, carrying huge volumes of heterogeneous passenger and freight traffic (Akimoto, 2003; Automotive Research Association of India, 2007; Central Pollution Control Board, 2010). The development of cities is one of the major roles for the connectivity of road network (Ohara et al., 2007; OICA Correspondents Survey, 2010). The vehicular traffic is recognized as one of the major sources of air pollution in Delhi exhibiting noticeable impact on air quality of the region (Gurjar et al., 2004; Garg et al., 2006; Goyal et al., 2006; Guttikunda and Calori, 2013). These vehicular emissions are important because they account for a major share of VOC, $\mathrm{NO}_{x}$, and $\mathrm{CO}$ emissions. They provide the majority of the most photo chemically reactive anthropogenic VOCs, and these emissions are localized in urban areas, which account for the majority of the National Ambient Air Quality Standard (NAAQS) violations (Parrish, 2005). Although there has been significant reduction in the concentration of $\mathrm{PM}_{10}, \mathrm{SO}_{2}$, sulfate aerosols and CO concentrations in Delhi due to metro rail operation and conversion of diesel/petrol based public vehicles to the ones driven by compressed natural gases (CNG) but the effect has been negated by a large increase in population of diesel-fueled cars (Narain and Krupnik, 2007). Nearly 94 percent vehicles are privately owned (cars and two-wheelers), while public transport like buses are just $1 \%$ of the total vehicular fleet (State of Environment Report for Delhi, 2010). With increase in city size, the traveling distance has become longer; the relative importance of walking and cycling has come down significantly (Ramachandra and Shwetmala, 2009). The traffic density, types of vehicles, poor road conditions etc., contribute as major sources for ambient air quality of environment (Kaushar et al., 2013). Even though the anthropogenic emissions are independent of seasons, the impact is more during the winter season due to the confinement of aerosols added with insignificant removal mechanisms. Toward summer, as the land gets dry due to increased solar heating, the conditions become more conducive for picking up of dust from arid and semi-arid regions of central western India. The dust storm episodes produce enormous amount of coarse-mode natural aerosols causing substantial reduction in visibility and radiation flux reaching the surface during summer (Gautam et al., 2010; Pandithurai et al., 2008; Prasad et al., 2007; Singh et al., 2006). The Delhi aerosol is best represented by a combination of urban and desert aerosol types which is the result of the coarse sand and dust particles being gradually added in already polluted (vehicular and industrial origin) atmosphere of Delhi (Singh et al., 2005). PAHs and VOCs are of major health concern due to their highly toxic, carcinogenic 
and mutagenic properties (IARC, 1984). PAHs and VOCs are mostly produced from incomplete combustion of biomass fuels and fossil fuels, and are almost entirely of anthropogenic origin (Seinfeld and Pandis, 1998). Knowledge of ambient levels of PAHs and VOCs is necessary to evolve a proper strategy to control troposphere ozone build up and maintain healthy air quality, since VOCs have also been identified as reactive precursors in the atmosphere, leading to the formation of ozone and photochemical smog. Recent studies were conducted to determine the major sources of PAH and VOC in the ambient air of Delhi and the automobiles running on diesel fuel were found as a major contributor of PAH and gasoline fuel were considered as a prime source of VOCs. The toxic compounds with potential health impacts include volatile organic compounds (VOCs) like benzene, total VOC and total polycyclic aromatic hydrocarbons (PAHs). Current developments in engine design and fuel quality are expected to reduce these emissions in the future. In India, a number of such vehicles are plying on the road whose age is already exceeded 10 years and they are making a major contribution towards city pollution which leads to bad health effects. Keeping in mind the bad scenario of the capital city, Delhi Government has banned the 10-year-old vehicle inside Delhi city. Considering the complexity of the air quality problem in Delhi, the worsening air quality will have a profound influence on the environment. The simulations conducted for the year 2010 to 2030 for temperature vs. increase in concentrations of air pollutants showed that there would be a net increase in mean temperature at the surface by approximately $25 \%$ (Marrapu, 2012).

\section{Research Methodology}

\subsection{Study Area: Delhi}

Fig. 1. represents the sampling points of study area. Total area of the National Capital Territory of Delhi is 1483 square kilometer (Delhi Statistical Handbook, 2012; Economic Survey of Delhi, 2014). The study domain extends from $28.3^{\circ} \mathrm{N}$ to $29.0^{\circ} \mathrm{N}$ and $76.76^{\circ} \mathrm{E}$ to $77.46^{\circ} \mathrm{E}, \sim 238 \mathrm{~m}$ above mean sea level.

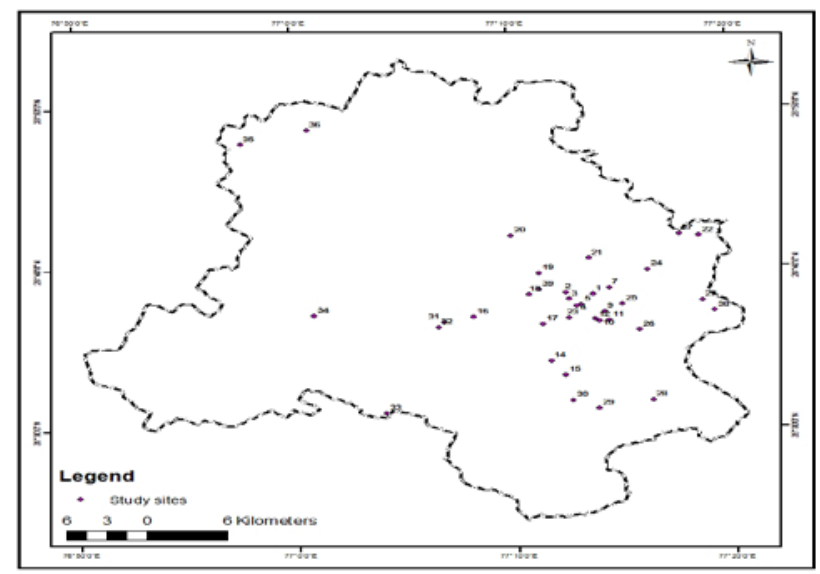

Fig. 1.

Sampling Locations of Study Areas 


\subsection{Emission from Road Transport Corridor}

The Box Model is used for the calculation of emission and Gaussian equation for concentration of the pollutant emitted from various vehicles (Fig. 2).

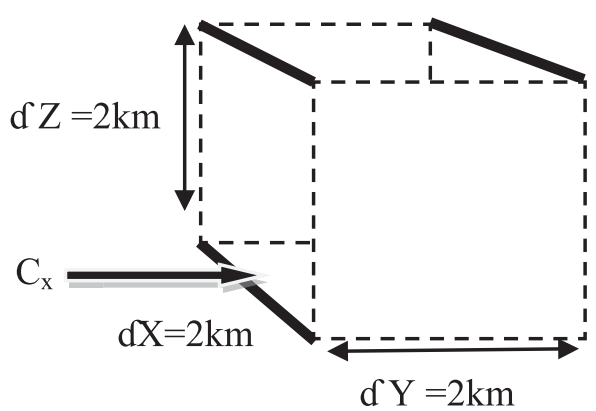

Fig. 2.

Flow Diagram of Box Model

In this model:

$\mathrm{C}_{\mathrm{x}}=$ Outside concentration of the pollutant;

$c(x, y, z)=\frac{Q}{2 \pi u \sigma_{y} \sigma_{z}} \exp \left[\frac{-1}{2}\left(\frac{y}{\sigma_{y}}\right)\right]\left[\exp \left(-\frac{(z+h)^{2}}{2 \sigma_{z}^{2}}\right)+\exp \left(-\frac{(z-h)^{2}}{2 \sigma_{z}^{2}}\right)\right]$

Emission $Q_{4}=$ Mass $/$ Area Time;

Accumulation $=$ Input to the Box (mass/time)

- (Output Box mass/time);

So, $\mathrm{Q}_{\mathrm{A}}$ or $\mathrm{E}_{\mathrm{t}}=$ Emission;

$\mathrm{C}_{\mathrm{x}}=$ Outside concentration of the pollutant;

Where,

$\mathrm{C}(\mathrm{x}, \mathrm{y}, \mathrm{z})$ is the concentration of pollutant unit $\left(\mu \mathrm{g} / \mathrm{m}^{3}\right)$ at receptor, coordinates $\mathrm{x}, \mathrm{y}, \mathrm{z}$ represent points;

Emission $Q_{A}=$ Mass/Area Time;

$Q$ is the rate of emission of pollution source

Accumulation=Input to the Box (mass/time)

- (Output Box mass/time);

$(\mu \mathrm{g} / \mathrm{sec})$;

Therefore, $\mathrm{Q}_{\mathrm{A}}$ or $\mathrm{E}_{\mathrm{t}}=$ Emission is presented in (eq. 1):

$\mathrm{u}=$ represents average speed of wind (meter/ second);

$y=$ cross wind distance (meter);

$\mathrm{z}=$ vertical distance (meter);

$E_{\mathrm{t}}=\sum\left(\right.$ Vehl $\left.* D_{l}\right) * E F_{l}$

Where, $\sigma_{\mathrm{y}}=$ represent standard deviation of plume in direction of y coordinate (meter);

$E_{\mathrm{t}}=$ Total Emission rate of compound (g/ $\sigma_{\mathrm{z}}=$ represent standard deviation of plume $\mathrm{Sec}$ );

Vehl represents the Number of Vehicle per in direction of $\mathrm{z}$ coordinate (meter);

type per hour;

$\mathrm{D}_{1}$ is the Distance traveled $2 \mathrm{~km}$;

$\mathrm{EF}_{1}, \mathrm{~km}=$ Emission Factor of pollutant, vehicle type per driven kilometer;

Assessment of Line source emission of pollutants is shown in line of infinitesimal point source.

The ground level concentration of gaseous pollutants can be estimated by integration 
of (eq. 2) along the length of the line source. Source of emission at ground level, $y=0, z=0$ According to abovementioned, concentration is (eq. 3):

$$
c(x, 0,0)=\frac{Q}{\pi u \sigma_{y} \sigma_{z}}
$$

The concentration is calculated distance $\mathrm{x}=0.02 \mathrm{~km}$ far from the emission points, (Luhar \& Patil 1986; Turner, 1994).

\section{Results and Discussions}

\subsection{Emission and Concentration}

The estimation of concentration was based on the emission rate of pollutants from different category of vehicles at various transport corridors in Delhi (Keelor, 2011). Due to the fact, that the individual variation between vehicles in terms of on-road emissions may be varied significantly even if the vehicles belong to the same subsector and technology class. Average concentration loads of benzene, poly aromatic hydrocarbons and volatile organic compounds from motor vehicles at 36 transport corridors in Delhi are presented in below figures. The figures show the estimated emissions as well as concentrations of various pollutants along selected corridors.

\subsubsection{Benzene Emission}

Benzene emission from transport sector in Delhi which was recorded maximum at I.T.O. Bridge ( $3.8 \mathrm{~kg} /$ day) followed by Nizamuddin Bridge and Punchkuin Road, whereas Auchandi Road and Old Gurgaon recorded minimum emissions respectively (below $1 \mathrm{~kg} /$ day). As shown in the Figure 3 , the emission ranged from a peak value close to $4 \mathrm{~kg} /$ day to a minimum value near $0.015 \mathrm{~kg} /$ day recorded at I.T.O. Bridge and Auchandi Road stretches whereas most of the roads exhibited values in the range of 0.5 to $2 \mathrm{~kg} / \mathrm{day}$.

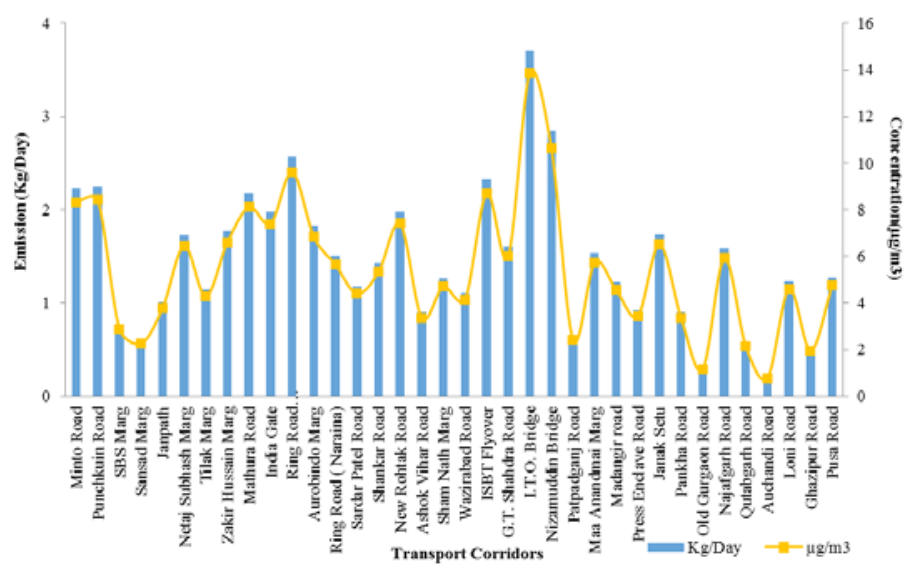

Fig. 3.

Emissions vs. Concentration of Benzene at Different Transport Corridors

Along with the estimation of Benzene emission, the concentration of Benzene was also calculated at 36 various roads of Delhi megacity. From the study, 18 
transport corridors were found in such a state, where the Benzene concentration was violating National Ambient Air Quality Standards (NAAQS) which is $5 \mu \mathrm{g} / \mathrm{m}^{3}$. The highest concentration was observed at I.T.O. Bridge $\left(13.9 \mu \mathrm{g} / \mathrm{m}^{3}\right)$ followed by Nizamuddin Bridge, Ring Road, ISBT Flyover, Punchkuian Road, Minto Road, Mathura Road, New Rohtak Road, India Gate, Aurobindo Marg, Zakir Hussain Marg, JanakSetu, Netaji Subhash Marg, G.T. Shahdra Road, Najafgarh Road, Maa Anandmai Marg, Ring Road (Naraina) and Shankar Road $\left(5.3 \mu \mathrm{g} / \mathrm{m}^{3}\right)$. The remaining corridors were found to be within the permissible limits.

\subsubsection{Total Polycyclic Aromatic Hydrocarbons (PAHs)}

Total PAHs emission from transport sector was also estimated at 36 road transport corridors of Delhi (Fig. 4). Among all the corridors, the highest emission was found at ISBT flyover i.e. $86.22 \mathrm{~kg} /$ day, while as many as 4 transport corridors like I.T.O. Bridge, Wazirabad Road, Zakir Hussain Marg and Nizamudding Bridge closely followed ISBT flyover with respect to total PAHs emission. Several roads, namely, India Gate, Maa Anandmai Marg, Mathura Road, Minto Road, Punchkuin Road and Ring Road (Naraina) were reported emitting the similar values of total PAHs followed by remaining roads presenting emission values remaining in the range of $10-40 \mathrm{~kg} / \mathrm{day}$.

As it is shown in the below figure, the emission ranged from a peak value slightly above $80 \mathrm{~kg} /$ day of total PAHs at ISBT flyover to a minimum value near $10-12 \mathrm{~kg} /$ day clocked at Patpadganj Road and Sansad Marg. Other roads reported values between 12 and $75 \mathrm{~kg} /$ day of PAHs emission.

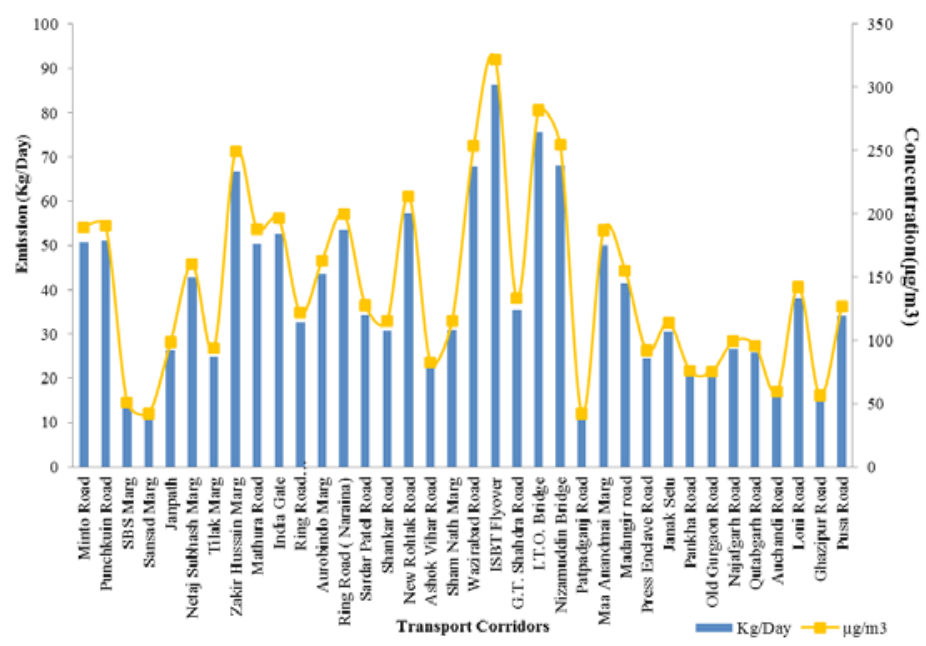

Fig. 4.

Emissions vs. Concentration of PAH at Different Transport Corridors

In addition to emission estimation, the trend of total PAHs concentration was also presented in above mentioned figure 4 . From the figure, it is clear that the maximum 
concentration of total $\mathrm{PAH}$ was also reported for ISBT flyover $\left(300.12 \mu \mathrm{g} / \mathrm{m}^{3}\right)$ narrowly followed by I.T.O. Bridge, Wazirabad Road, Zakir Hussain Marg and Nizamudding Bridge. Between relatively upper reach of the graph $\left(100-200 \mu \mathrm{g} / \mathrm{m}^{3}\right)$, there were found as many as 17 roads reporting such values, where as remaining roads in the megacity perform relatively worse depicting total PAHs values in the range of $50-100$ $\mu \mathrm{g} / \mathrm{m}^{3}$ (in the lower reach of graph), with Patpadganj Road and Sansad Marg reporting lowest concentration at about $50 \mu \mathrm{g} / \mathrm{m}^{3}$.

\subsubsection{Total Volatile Organic Compounds (VOCs)}

Along with above mentioned toxic pollutants, the emission of total volatile organic compounds was also estimated at selected corridors in Delhi and the highest VOCs was found at Nizamuddin Bridge (516.4 kg/day) closely followed by I.T.O. bridge. While roads, viz. India Gate, Ring Road (Safdarjung) and Mathura Road were reported to be third highest emitters of total VOC on the city roads, whereas Aurobindo Marg and Minto Road reported slightly lesser values (Fig. 5). Most of the remaining roads like Janak Setu, Panchkuian Road, Shankar Road and New Rohtak Road reported values of emission in the relatively upper reach, whereas Ghazipur Road, Old Gurgoan Road and Qutabgarh Road were found to be reporting emission values in the lower reach of the graph. Among all the transport corridors, the lowest emission was found at Auchandi road (20 kg/day).

The data obtained and plotted for the trend of average VOCs concentration on the roads of Delhi shown in Figure 5. It can be observed that highest concentration was noted at Nizamuddin Bridge at just below $2000 \mu \mathrm{g} /$ $\mathrm{m}^{3}$ whereas the lowest concentration of VOCs was reported for Auchandi Road $(<100 \mu \mathrm{g} /$ $\mathrm{m}^{3}$ ). A close look at graph reveals that I.T.O. Bridge follows as second highest emitter of VOCs at about $1750 \mu \mathrm{g} / \mathrm{m}^{3}$ whereas India Gate and Ring Road (Safdarjung) reported values just at $1500 \mu \mathrm{g} / \mathrm{m}^{3}$ of the variable inquestion. While upper reach of the graph (for values between $500-1500 \mu \mathrm{g} / \mathrm{m}^{3}$ ) covers as many as 25 roads, remaining 11 roads occupy lower reach of graph (for value of below $500 \mu \mathrm{g} / \mathrm{m}^{3}$ ).

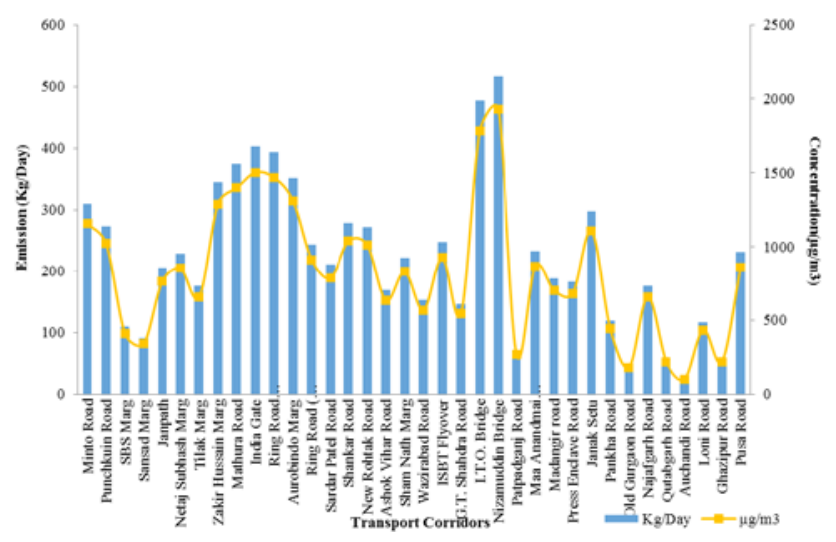

Fig. 5.

Emissions vs. Concentration of VOCs at Different Transport Corridors 


\section{Conclusion}

The estimation of traffic induced emission as well as concentration was perform to quantify the emission as well as concentration of benzene, total poly aromatic hydrocarbons and total volatile organic compounds at 36 major transport corridors of Delhi. The highest emission of benzene, total poly aromatic hydrocarbons and total volatile organic compounds was found at ITO Bridge $(3.71 \mathrm{~kg} /$ day $)$, ISBT Flyover $(86.2 \mathrm{~kg} /$ day) and Nizamuddin Bridge ( $516.4 \mathrm{~kg} /$ day) respectively, whereas the minimum was observed at Auchandi Road, Sansad Marg and again Auchandi road correspondingly. On the other hand, the observations related to quantification of concentration showed that 18 transport corridors surpass the National Ambient Air Quality Standards for benzene. Like emission scenario of three toxic pollutants, the maximum concentrations of the same pollutants (benzene, total poly aromatic hydrocarbons and total volatile organic compounds) was found at ITO Bridge $\left(13.6 \mu \mathrm{g} / \mathrm{m}^{3}\right)$, ISBT Flyover $\left(322 \mu \mathrm{g} / \mathrm{m}^{3}\right)$, and Nizamuddin Bridge $\left(1929.3 \mu \mathrm{g} / \mathrm{m}^{3}\right)$ respectively, whereas the minimum was found at Auchandi Road, Sansad Marg and again Auchandi road correspondingly. All the 36 transport corridors were found under higher concentration of toxic pollutants. The higher emission as well as concentration of benzene, total poly aromatic hydrocarbons and total volatile organic compounds at the above mentioned corridor may be due to higher traffic volume, higher percentage of heavy vehicles, presence of more traffic signals and stagnation of vehicles at flyover for a long period of time during peak hours, traffic congestion etc. Keeping in mind the emission and concentration of above discussed toxic pollutants, special attention like integrative traffic management plan may be required to curb the pollution level.

\section{Acknowledgement}

The authors would like to thank Department of Environmental Engineering, DTU Delhi, India for supporting the instrumentation for monitoring and assessment of study area.

\section{References}

Akimoto, H. 2003. Global Air Quality and Pollution, Science 302(5651): 1716-1719.

Automotive Research Association of India. 2007. Emission Factor Development for Indian Vehicles, Air Quality Monitoring Project-Indian Clean Air Programme. New Delhi.

Central Pollution Control Board. 2010. Air Quality Monitoring, Emission Inventory and Source Apportionment Study for Indian Cities, New Delhi, 1-658.

Chan, T.L.; Ning, Z.; Leung, C.S.; Hung, W.T.; Dong, G. 2004. On-road remote sensing of petrol vehicle emissions measured and emission factors estimations in Honk Kong, Atmospheric Environment 38(14): 2055-2066.

CPCB. 2010. Transport Fuel Quality for the Year. Central Pollution Control Board (CPCB), India.

Delhi Statistical Handbook. 2012. Government of National Capital Territory of Delhi, Delhi Statistical Handbook, Directorate of Economics \& Statistics, New Delhi.

Directorate of Economics and Statistics. 2014. Statistical Abstract of Delhi (2014-2015). Government of National Capital Territory of Delhi. 190 p. 
Drimal, M.; Lewis, C.; Fabianova, E. 2010. Health Risk Assessment to Environmental Exposure to Malodorous sulfur Compounds in Central Slovakia (Ružomberok Area), Carpathian Journal of Earth and Environmental Sciences 5(1): 119-126.

Economic Survey of Delhi. 2014. Department of planning, Gov. of NTC of Delhi India.

Elbir, T.; Mangir, N.; Kara, M.; Simsir, S.; Eren, T.; Ozdemir, S. 2010. Development of a GIS-based Decision Support System for Urban Air Quality Management in the City of Istanbul, Atmospheric Environment 44(4): 441-454.

Elbir, T.; Muezzinoglu, A. 2004. Estimation of Emission Strengths of Primary Air Pollutants in the City of Izmir, Turkey, Atmospheric Environment 38(13): 1851-1857.

Garg, A.; Shukla, P.A.; Kapshe, M. 2006. The Sectoral Trends of Multigas Emissions Inventory of India, Atmospheric Environment 40(24): 4608-4620.

Gautam, R.; Hsu, N.C.; Lau, K.M. 2010. Premonsoon aerosol characterization and radiative effects over the Indo-Gangetic Plains: Implications for regional climate warming, Journal of Geophysical Research: Atmospheres 115 (D17), doi:10.1029/2010JD013819.

Goyal, S.K.; Ghatge, S.V.; Nema, P.S.M.T.; Tamhane S. 2006. Understanding Urban Vehicular Pollution Problem vis-a-vis Ambient Air Quality-Case Study of a Megacity (Delhi, India), Environmental monitoring and assessment 119(1): 557-569.

Gurjar, B.R.; Van Aardenne, J.A.; Lelieveld, J.; Mohan, M. 2004. Emission estimates and trends (1990-2000) for megacity Delhi and implications, Atmospheric Environment 38(33): 5663-5681.

Guttikunda, S.K.; Calori, G. 2013. A GIS Based Emissions Inventory at $1 \mathrm{~km} x 1 \mathrm{~km}$ Spatial Resolution for Air Pollution Analysis in Delhi, India, Atmospheric Environment 67(1): 101-111.
IARC (International Agency for Research on Cancer). 1984. Summary of Data Reported and Evaluation, World Health Organization. USA.

Kandlikar, M.; Ramachandran, G. 2000. The Causes and Consequences of Particulate Air Pollution in Urban India: A Synthesis of the Science, Annual review of energy and the environment 25(1): 629-684.

Kaushar, A.; Chate, D.; Beig, G.; Srinivas, R; Parkhi, N.; Satpute, T.; Sahu, S.; Ghude, S.; Kulkarni S.; Surendran, D.; Trimbake, H. 2013. Spatio-Temporal Variation and Deposition of Fine and Coarse Particles during the Commonwealth Games in Delhi, Aerosol and Air quality research 13(2): 748-755.

Keelor, V. 2011. Streamlining Traffic, Survey Studies Choke Points. Times of India.

Luhar, A.K.; Patil, R.S. 1986. Estimation of Emission Factors for Indian Vehicles, Indian Journal of Air Pollution Control 7(4): 155-160.

Marrapu, P. 2012. Local and Regional Interactions between Air Quality and Climate in New Delhi: A Sector Based Analysis. PhD thesis, University of Iowa, Available from Internet: <http://ir.uiowa.edu/etd/3497>.

Marrapu, P.; Cheng, Y.; Beig, G.; Sahu, S.; Srinivas, R.; Carmichael, G.R. 2014. Air Quality in Delhi during the Commonwealth Games, Atmospheric chemistry and physics 14(19): 10619-10630.

Ministry Of Finance (MoF). 2000. Govt. of India Economic Survey 1999-2000 New Delhi. Available from Internet: $<$ http://finmin.nic.in $>$.

Mishra R.K.; Shukla A.; Parida, M.; Rangnekar, S. 2014. EIA Based Comparative Urban Traffic Noise Analysis Between Operational and Under Construction Phase Public Transport Corridor, International Journal for Traffic and Transport Engineering 4(3): $352-362$. 
Mohan, M.; Dagar, L.; Gurjar, B.R. 2007. Preparation and Validation of Gridded Emission Inventory of Criteria Air Pollutants and Identification of Emission Hotspots for Megacity Delhi, Environmental monitoring and assessment $130(1): 323-339$.

Narain, U.; Krupnick, A. 2007. The impact of Delhi's CNG program on air quality, RFF Discussion Paper, 07-06.

Ohara, T.A.H.K.; Akimoto, H.; Kurokawa, J.I.; Horii, N.; Yamaji, K.; Yan, X.; Hayasaka, T. 2007. An Asian Emission Inventory of Anthropogenic Emission Sources for the Period 1980-2020, Atmospheric Chemistry and Physics 7(16): 4419-4444.

OICA Correspondents Survey, World Motor Vehicle Production by Country and Type, 2009-2010.

Pandithurai, G.; Dipu, S.; Dani, K.K.; Tiwari, S.; Bisht, D.S.; Devara, P.C.S.; Pinker, R.T. 2008. Aerosol radiative forcing during dust events over New Delhi, India, Journal of Geophysical Research: Atmospheres 113(D13), doi:10.1029/2008JD009804.

Parrish, D.D. 2005. Critical Evaluation of US On-road Vehicle Emission Inventories, Atmospheric Environment 40(13): $2288-2300$.

Prasad, A.K.; Singh, S.; Chauhan, S.S.; Srivastava, M.K.; Singh, R.P.; Singh, R. 2007. Singh. Aerosol radiative forcing over the Indo-Gangetic plains during major dust storms, Atmospheric Environment 41(29): 6289-6301.
Ramachandra, T.V. 2009. Emissions from India's transport sector: Statewise synthesis, Atmospheric Environment 43(34): 5510-5517.

Rao, J.S. 2013. PM10, NOx Level High in Gurgaon. Times of India.

Seinfeld, J.H.; Pandis, S.N. 2006. Atmospheric Chemistry and Physics: From Air Pollution to Climate Change. $2^{\text {nd }}$ Edition. John Wiley \& Sons, Inc. USA. 1152 p.

Singh, S.; Singh, B.; Gera, B.S.; Srivastava, M.K.; Dutta, H.N.; Garg, S.C.; Singh, R. 2006. A study of aerosol optical depth in the central Indian region $\left(17.3-28.6^{\circ} \mathrm{N}\right)$ during ISRO-GBP fieldcampaign,Atmospheric Environment 40(34): 6494-6503.

Singh, S.; Nath, S.; Kohli, R.; Singh, R. 2005. Aerosol over Delhi during Pre-monsoon Months: Characteristics and Effect on Surface Radiation Forcing, Geophysical Research Letters 32(13): 1-4.

State of Environment Report (SOE). 2010. Delhi Department of Environment and Forests Government of NCT of Delhi, Level 6, C Wing Delhi Secretariat, New Delhi, 1-137.

Turner, D.B. 1994. Work book of atmospheric dispersion estimates: an introduction to dispersion modeling. Lewish Publisher, $2^{\text {nd }}$ Edition, 635 p. 